\title{
Epidemiology of Avian Infectious Laryngotracheitis with Special Focus to South America: an update.
}

http://dx.doi.org/10.1590/1806-9061-2016-0224

Review

-Author(s)

\section{Parra SHSI \\ Nuñez LFN'}

Ferreira AJPI

Department of Pathology, School of Veterinary Medicine, University of São Paulo, Av. Prof. Dr. Orlando M. Paiva, 87, São Paulo SP, 05508-270, Brazil.

\section{-Mail Address}

Corresponding author e-mail address Antonio J. Piantino Ferreira

Av Prof Dr Orlando M. Paiva, 87 - São Paulo - SP - Brasil - Zip code: 05508-270

Tel: $\quad+$ (5511) 3091-1352

Email: ajpferr@usp.br

\section{- Keywords}

Avian infectious laryngotracheitis, biosecurity, epidemiology, South America, chicken.

\section{ABSTRACT}

Avian Infectious laryngotracheitis (AILT) is a respiratory tract disease of great importance because it causes significant economic losses in the poultry industry around the world. It is caused by a Gallid herpesvirus type 1, a member of the genus I/tovirus. The target system for Avian Infectious Laryngotracheitis virus (AILTV) infections is the respiratory system, and the main organ in which the virus remains latent is the trigeminal ganglia. However, the virus has demonstrated tropism for other organs besides the respiratory tract. The main transmission routes are ocular and respiratory. Infected birds with clinical symptoms are main sources of transmission, but birds with latent infections, litter, and contaminated fomites may also transmit the virus. Clinical signs usually appear 6-12 days after natural exposure and may be moderate or severe. The causative agent of this disease can be propagated in chorioallantoic membrane (CAM) of developing chicken embryos and replicate in mature chicken kidney cells, as well as in a variety of epithelial chick embryo cells, such as kidneys, liver and lungs. There are several procedures for the diagnosis of ILT such as the observation of clinical signs, the detection of gross and histopathological lesions, and the use of molecular techniques, including RFLP, polymerase chain reaction $(P C R)$, real-time $P C R$, and loop-mediated isothermal amplification. Vaccination with different types of vaccine provides a good expectation on disease control, such as vaccines produced in chicken-embryo-origin (CEO), tissue-culture-origin (TCO), and recombinant vaccines. However, in endemic areas, biosecurity measures and best management practices are important for the control of the disease. It is distributed worldwide and, in South America, it has been reported in Brazil, Peru, Ecuador, Bolivia, and Argentina causing great economic losses.

\section{INTRODUCTION}

Avian Infectious laryngotracheitis (AILT) is a highly contagious disease. Chickens are the primary host (Bagust et al., 1986) but it may affect pheasants and chicken. Starlings, sparrows, crows, pigeons and ducks seem to be resistant to the virus (Guy \& Garcia, 2008). The causative agent is a pneumotropic virus of the family Herpesviridae, genus Iltovirus. Taxonomically, this virus is classified as a Gallidherpesvirus 1 (King et al., 2012). This disease is included in the OIE list of mandatory notification of diseases of terrestrial and aquatic animals, as well as for the Brazilian Official Service (http://www.oie.int/en/animal-healthin-the-world/oie-listed-diseases-2014/). It causes severe lesions in the respiratory tract and great economic losses due to mortality, decreased egg production, weight loss, and susceptibility to infections with other aviary pathogens (Guy \& Garcia, 2008).

The severe form causes significant respiratory distress, expectoration of bloody sputum, sneezing, and high mortality. The mild form is 
characterized by mucoid tracheitis, sinusitis, and low mortality (Ou \& Giambrone, 2012).

The disease was first described in 1925 (May \& Tittsler, 1925), and has been reported in many countries in which remains an endemic disease, especially in areas of intensive poultry production, with great concentration of poultry farms rearing birds with multiple ages, including North America, China, Europe, Australia, Africa, Southeast Asia, New Zealand, Australia, Poland, South America, and Brazil (Hidalgo, 2003; Chacón \& Ferreira, 2009).

The virus is horizontally transmitted, and the primary virus replication sites are in the tracheal mucosa and conjunctiva, where it can cause inflammation, mucoid or serous discharge, cough, and dyspnea (Coppo et al., 2013a). The virus can invade the trigeminal nerve during the lytic phase of infection, resulting in a latent infection that may remain throughout the life of the animal, and some stressors, such as placement with other birds and the onset of egg laying, can cause reactivation of replication and viral excretion (Hughes et al., 1989; Hughes et al., 1991; Coppo et al., 2013a; Williams et al., 1992). New experimental studies show that the virus can also be detected in other organs, such as the heart, liver, spleen, lung, kidney, tongue, thymus, proventriculus, pancreas, duodenum, small intestine, large intestine, cecum, cecal tonsils, bursa, and brain (Zhao et al., 2013; Wang et al., 2013; Oldoni et al., 2009; Parra et al., 2015a).

The importance of the Avian Infectious Laryngotracheitis virus for poultry demands constant update of our knowledge on this respiratory disease. This review article discusses virus characteristics, pathology, immunology, diagnosis methods, description of diseases and the main control strategies, with special focus on South America.

\section{DESCRIPTION OF THE AGENT AND DISEASE}

\section{Etiology}

The avian infectious laryngotracheitis virus belongs to the family Herpesviridae, subfamily Alphaherpesvirinae, genus Iltovirus, and it is taxonomically classified as a Gallidherpesvirus type 1. The subfamily includes important human and animal pathogens, such as human herpesvirus 1 (Simplex virus); pseudorabies swine virus and varicella zoster virus (Varicellovirus), and other alphaherperviruses, such as that causes Marek's disease (Johnson \& Tyack, 1995).

This DNA virus has icosahedral symmetry, measures 195- $250 \mathrm{~nm}$ in diameter, has a density of $1.704 \mathrm{~g} /$
$\mathrm{mL}$, and molecular weight of approximately $1 \times 10^{8}$. Its genome consists of a linear double-stranded molecule of $155 \mathrm{~kb}$, with a unique long region (UL) and a unique short region (US), flanked by inverted repeats (Johnson et al., 1991; Bagust et al., 2000).

\section{Susceptibility to chemical and physical agents}

The ILTV is sensitive to lipolytic agents, such as ether and chloroform, but can survive for several months stored in suitable diluents, such as glycerol (50\%) and sterile skimmed milk at $4^{\circ} \mathrm{C}$ (Bagust et al., 2000). The virus is also able to survive in chicken tracheal exudate and carcasses for 10-100 days at room temperature between 13-23 ${ }^{\circ} \mathrm{C}$ (Jordan, 1966). Chemical disinfectants derived from coal tar, formaldehyde, hypochlorite, and iodophor can effectively inactivate the virus (Guy \& Garcia, 2008). In addition, the virus may be inactivated by solutions of $3 \%$ or $5 \%$ cresol in less than one minute and the use of $5 \%$ hydrogen peroxide results efficient disinfection of poultry equipment (Neighbour et al., 1994). Commercially available biofilm-reducing sanitizers are effective for removing residual vaccine virus from water lines and nipple drinkers after consecutive flock vaccination via drinking water (Ou et al., 2011).

\section{Laboratory host systems}

The laryngotracheitis virus can be propagated in embryonated eggs, which induce the formation of opaque plaques on the chorioallantoic membrane (CAM) observed 48 hours post-infection (hpi), and embryonic death occurs between 2-8 days postinfection (dpi). ILTV has been propagated in a variety of avian cell cultures, such as chicken embryo liver (CEL), chicken embryo kidney (CEK), and chicken kidney cell cultures (CK). The virus causes rounding of the nucleoli, chromatin displacement, increase of refractiveness, swelling of cells, as well as syncytium formation as the result of cytoplasmic fusion (Hughes \& Jones, 1988; Garcia et al., 2014). Chicken embryo liver cells are the most susceptible for the primary isolation of the virus from clinical material (Garcia et al., 2014). On the other hand, chicken embryo fibroblast cells, Vero cells, and quail cells have little susceptibility to the growth of virus derived from field material (Schnitzlein et al., 1994; Garcia et al., 2014). Furthermore, the virus may be propagated in LMH (leghorn male hepatoma) cells, a cell line derived from a chemically-induced chicken liver tumor, and it is used by research laboratories for the study of virus-host interactions (Schnitzlein et al., 1994). 


\section{Hosts}

Chickens of all ages are susceptible to the infection by the laryngotracheitis virus, but birds older than three weeks are more sensitive (Ou \& Giambrone, 2012). The virus can also infect pheasants, pheasants-chicken crosses, peacocks, and young turkeys (Crawshaw \& Boycott, 1982; Portz et al., 2008). Starlings, sparrows, crows, doves, ducks seem to be refractory to the virus (Guy \& Garcia, 2008). ILTV was also isolated from a guinea fowl in a farm with a history of respiratory disease (Bautista, 2003). Subclinical ITLV infection and seroconversion was demonstrated in ducks (Yamada et al., 1980).

\section{Transmission}

The of ILTV is naturally transmitted by the upper respiratory tract and also by ocular route. Ingestion may also cause infection; however, the nasal epithelium needs to be exposed after virus ingestion (Robertson \& Egerton, 1981). The main sources of transmission are clinically-affected chickens, latent carrier animals, contaminated dust, litter beetles, drinking water, and fomites (Ou et al., 2011). Recent studies have shown that the virus may remain in the biofilm water and subsequently be transmitted to susceptible birds (Ou \& Giambrone, 2012). Other possible sources of transmission are dogs, cats, and crows (Kingsburry \& Jungherr, 1958). Airborne transmission among farms is also very important for the spread of the virus (Johnson et al., 2005).

\section{Acute and latent infection}

The target organ for infection and disease development is the respiratory epithelium. The trachea and larynx epithelia are the most affected, although other mucous membranes, such as the conjunctiva, nasal sinuses, air sacs, and lung tissue can be occasionally infected. When the birds are exposed to the virus by oral, nasal, or conjunctival route or by experimental inoculation in the breast, the virus replicates in the tracheal epithelium. Viral replication occurs only during the first week after infection, although low levels of the virus may be sporadically detected ten days after infection (Bagust, 1986; Williams et al., 1992). From approximately ten days to four weeks after infection, tracheal spread of the infection can be stopped, but a latent phase of infection may be established by the invasion of nervous tissues. Trigeminal nerve invasion by the virus can occur between days three and six in the acute phase of infection by either field or vaccine strains (Bagust, 1986). The precise route of infection of the trigeminal ganglion is unknown, but this nerve provides sensory innervation to the tissues of the upper respiratory tract, tongue and eyes, and the distal part of the nerve is also involved in the innervation of the trachea (Bagust, 1986; Williams et al., 1992; Bagust \& Johnson, 1995). Studies using PCR indicate that the trigeminal ganglion is the main organ of virus latency (Williams et al., 1992). The virus can be reactivated from the trigeminal nerve 15 months post-vaccination and the viral DNA can be detected two days later in birds vaccinated by ocular route (Rodriguez-Avila et al., 2007; Williams et al., 1992). Virus shedding may considerably increase when birds are subjected to stress, such as the beginning of the laying period or when are mixed with unknown birds. In this case, birds with latent infection may act as reservoirs and cause infection in susceptible animals (Hughes et al., 1991; Williams et al., 1992).

\section{Clinical signs}

The disease has severe and mild forms. In the severe form, the main clinical signs are overt dyspnea and bloody mucus, moderate to severe conjunctivitis, and there may be high morbidity (90-100\%) and mortality, which may be higher than $70 \%$, but usually is in the range of $10 \%-20 \%$. Also, inflammation and necrosis are observed with hemorrhage in the mucosa and in the respiratory tract (Bagust et al., 2000; Garcia et al., 2014). In the mild enzootic form, the observed signs are depression, decreased egg production, non-thriftiness, conjunctivitis, swelling of the infraorbital sinuses (almond eyes), mild mucoid tracheitis, respiratory rales, mild hemorrhagic conjunctivitis, and persistent nasal discharge; morbidity and mortality may reach $5 \%$ and $0.1-2 \%$, respectively (Raggi et al., 1961; Ou et al., 2012). Birds may recover in 10 to 14 days, but the clinical signs caused by the infection with some strains continue for a few weeks (Guy \& Garcia, 2008; Garcia et al., 2014; Ou et al., 2012). The clinical signs appear after 6-12 days of natural exposure; however, in experimental infections. the incubation period is shorter, of around 4-7 dpi (Garcia et al., 2014).

\section{Lesions}

Gross lesions may be observed in the conjunctiva and the entire respiratory tract of infected birds, but are most frequently seen in the larynx and trachea. In the severe form, mucoid inflammation is observed in the early stages, and hemorrhage, degeneration and necrosis are observed in later stages. The inflammation may extend down to the bronchi, lungs, and air sacs. Diphtheritic changes, present as mucoid casts, may 
affect the entire length of the trachea (Garcia et al., 2014). In the mild form, moderate mucoid tracheitis, presenting varying hemorrhage degrees in the larynx and upper trachea, is observed (Sellers et al., 2004).

Microscopic lesions vary with the stage of the disease. In the first days, goblet cells and infiltration of the tracheal mucosa with inflammatory cells are increased. As the infection progresses, epithelial cells of the conjunctiva and respiratory tract become enlarged and edematous, and multinucleated cells form syncytia. Lymphocytes, histiocytic, and blood cells migrate into the mucosa and submucosa in 2-3 days (Garcia et al., 2014). Intranuclear inclusion bodies in the tracheal and conjunctival epithelial cells are present for a few days ( $1-5 \mathrm{dpi}$ ) in the early stages of infection, and then disappear due to necrosis and sloughing of the epithelium (Guy et al., 1992).

\section{Immune response to ILTV}

A variety of immune responses are generated after infection of ILTV (Garcia et al., 2014). Humoral immunity is not the main response against the virus (Ou \& Giambrone, 2012). In humoral response tests, such as virus neutralization and ELISA, antibodies are detected after 5-7 dpi, peak on $21 \mathrm{dpi}$, and may decline in the next months (Jordan, 1981) or persist for a year or longer (Bagust, 1986). Antibodies can be detected in tracheal secretions approximately $7 \mathrm{dpi}$ and peak 10-28 dpi (Garcia et al., 2014).

The cell-mediated immune response is considered of great importance in the resistance against AlLTV (Coppo et al., 2013b). Experiments have shown that birds bursectomized with cyclophosphamide and surgical methods the block their humoral immune developed cell-mediated immune response to the AILTV (York \& Fahey, 1990).

Studies suggest that the $\mathrm{gG}$ gene present in the ILTV genome functions as broad-spectrum viral chemokine binding protein (vCKBP). This protein presents similar characteristics as some poxviruses and the murine gamma herpesvirus 68 (MHV-98), and their function is to evade host immune responses (Coppo et al., 2013b). Maternal antibodies are transmitted to offspring via eggs (Benton et al., 1960), as shown by their presence in day-old chicks (Gharaibeh et al., 2008); however, they do not protect against infection or interfere with vaccination (Fahey et al., 1983).

\section{Vaccination}

Vaccination is the best method to prevent infection, but vaccinated birds may become latent infected carriers and be the source of virus transmission to non-vaccinated flocks. For this reason, vaccination is recommended in endemic areas (Andreasen et al., 1989). High levels of protection are obtained 15-20 weeks post-vaccination, with variables degrees of protection throughout the year (York et al., 1989; Fahey \& York, 1990).

The most frequently used vaccine strains are modified-live virus of Tissue Culture Origin (TCO) or Chicken Embryo Origin (CEO). There is no significant difference in bird immunity 10 weeks after vaccination when CEO and TCO vaccines are compared; however, after 20 weeks, CEO vaccines provide better protection than TCO vaccines (Andreasen et al., 1989).

The main administration routes of live vaccines are via spray and drinking water. Vaccination via drinking water may not be very effective due to water quality issues on different farms and because birds may not receive the amount of virus required to induce protection. Successful vaccination against ILTV requires the contact of the vaccine virus with the nasal epithelium cells (Robertson \& Egerton, 1981). On the other hand, spray vaccination may cause severe reactions, as some birds may receive an overdose and very small droplets can penetrate deep into the respiratory tract (Clarke et al., 1980). Some studies indicate that the virulence of modified live vaccines increases with bird-to-bird passage, and after the sixth passage, may produce severe clinical signs in challenged birds (Guy et al., 1991; Kotiw et al., 1995). Chicken-embryo origin vaccines (CEO) show a greater tendency to increase their virulence with bird-to-bird passage relative to those of tissue-culture origin (TCO) (Guy et al., 1991; Kotiw et al., 1995). Recent epidemiological studies indicate that the ILT outbreaks reported around the world are mainly related to the use of live attenuated vaccines (Menendez et al., 2014).

In recent years, recombinant vaccines are available in the market, and include the insertion of ILT viral glycoproteins into viral vectors, such as poxvirus (FPV) (Davison et al., 2006) and turkey herpesvirus (HVT) (Vagnozzi et al., 2012). A recombinant fowl pox vaccine, containing the gene encoding the glycoprotein B $(g B)$, was shown to protect chickens against virulent ILTV strains (Tong et al., 2011). Another avian pox recombinant vaccine, including the gene for glycoprotein $B(\mathrm{gB})$ and the UL32 gene, was effective against the challenge of a virulent ILTV strain applied in the wing (Coppo et al., 2013a). These recombinant vaccines do not cause latent infection or reversion to virulence. Despite being safer than live attenuated vaccines, their high cost and the fact that they must be injected have limited their use (Ou \& Giambrone, 2012). 
Studies have been conducted to develop new vaccines using gene deletions. Some viruses with deleted genes may retain their ability to induce immune response while not producing clinical signs or latency. ILT viruses with deletions of the genes $\mathrm{gC}$ (Pavlova et al., 2010), gG (Devlin et al., 2006), gJ (Fuchs et al., 2005), TK (Han et al., 2002), ULO (Veits et al., 2003), and UL 47 (Helferich et al., 2007) showed attenuation and may be used for vaccine production. A gG-deficient ILTV strain administered to 3-week-old SPF chickens via drinking water and eye drop induced adequate immunity against challenge with a wild strain and may potentially be used for large-scale vaccination; however, further studies are needed before it is applied to commercial poultry flocks (Devlin et al., 2008).

Vaccines using ILTV as recombinant viral vector to express highly pathogenic genes ( $\mathrm{H} 5$ and $\mathrm{H} 7$ ) of avian influenza have been tested and shown to protect chickens from both laryngotracheitis and avian influenza (Pavlova et al., 2009). A AlLTV vector with the HPAI H5 gene inserted in the deleted region of the UL50 gene protected chickens against challenges with homologous and heterologous H5N1 and H5N2 viruses, respectively (Pavlova et al., 2009). Another vaccine ILTV was developed using the gB gene combined with chicken IL-18 as a bicistronic vector and induced better protection of chickens challenged with ILTV that those containing only the $\mathrm{gB}$ gene as monocistronic vector (Chen et al., 2010).

\section{Diagnosis}

Infectious laryngotracheitis is usually diagnosed in the laboratory because other diseases cause very similar clinical signs and lesions, such as avian influenza, bronchitis, Newcastle's disease, infectious coryza, and mycoplasmosis. The diagnosis based on clinical signs is only reliable in cases of acute severe disease, with high mortality and expectoration of blood (Guy \& Garcia, 2008).

\section{Histopathology}

Infectious laryngotracheitis is characterized by the presence of eosinophilic intranuclear inclusion bodies, which are pathognomonic when present in the epithelial cells of the conjunctiva and of the respiratory tract. Those inclusion bodies are detected in the tissues by staining with Giemsa or with hematoxylin and eosin of tracheal section embedded in paraffin wax (Guy \& Garcia, 2008). Epithelial hyperplasia leads to the formation of multinucleated cells (syncytia) in which intranuclear inclusions bodies may be evidenced. In addition, the tracheal tissue is infiltrated by heterophils and lymphocytes (Fahey \& York, 1990). Lamina propria swelling is observed after hemorrhage, as well as epithelial sloughing and loss of mucous glands. Tissue regeneration starts after approximately six days, after which intranuclear inclusions bodies are no longer visible (Bagust et al., 2000). Rapid histopathology methods for tissue processing have been described, and include rapid dehydration of tissues to allow examination after three hours of processing (Pirozok et al., 1957; Sevoian, 1960). Although ILT histopathological diagnosis by the detection of intranuclear inclusion bodies is highly specific, virus isolation is more sensitive (Guy et al., 1992).

\section{Virus isolation}

The ILT virus can be isolated from clinical samples obtained from swabs, tissue homogenates, and trachea, larynx, lung, and conjunctiva exudates. The most sensitive isolation method is inoculation in the chorioallantoic membrane (CAM) of embryonated chicken eggs with 9 to 12 days (Hichtner et al., 1958). The virus causes the production of plaques with opaque edges and a central depressed area of necrosis (Garcia et al., 2014). The virus can also be isolated using cell cultures, particularly CEL and CK, although the CEL system is more sensitive. In cell cultures, multinucleated giant cells are detected $24 \mathrm{hpi}$. Both in CAM and cell culture systems, more than one passage is required virus isolation (Bagust et al., 2000). The samples should be collected as soon as possible after the establishment of clinical signs because isolation attempts are successful 6-7 days after infection (Guy et al., 1992).

\section{Other techniques of virus detection}

Other methods for ILTV detection include immunofluorescence (IF), immunoperoxidase (IP), virus neutralization (VN), enzyme-linked immunosorbent assay (ELISA), DNA hybridization techniques, electron microscopy (EM), and PCR (Bagust et al., 2000). The IF or IP are performed using sections or scrapings of the epithelium of affected birds. Viral proteins have been detected by IF for up to fourteen days after exposure (Wilks \& Kogan, 1979). It was shown that immunofluorescence can detect antibodies against ILTV in tracheal tissues $109 \mathrm{dpi}$ and that IP is more sensitive than the IF (Guy et al., 1992). Further studies have shown that ELISA, using monoclonal antibodies against ILTV, provides accurate ITLV detection, and it is faster and more accurate than IF or immunodiffusion in agar gel (Jordan \& Chubb, 1962). The use of direct electron microscopy is one of the fastest methods to 
detect the ILTV, but is not very sensitive and virus titers of at least $3.0 \log 10$ per gram are required to identify the viral particles (Bagust et al., 2000).

Some molecular methods for the detection of viral DNA can identify the virus faster, more accurately, and are highly sensitive. Molecular techniques include hybridization assays, dot-blot, and cloning of viral DNA, which are very sensitive for viral detection when viral isolation and ELISA results are negative (Keam et al., 1991; Key et al., 1994). There are also other methods like $P C R$, nested $P C R$, real-time $P C R$, multiplex $P C R$, in situ hybridization (Nagy, 1992; Nielsen et al., 1998), and PCR followed by restriction fragment length polymorphism (RFLP) (Chang et al., 1997; Kirkpatrick et al., 2006; Chacon et al., 2010). The detection of ILTV by PCR is more sensitive than virus isolation or electron microscopy and also allows detecting the virus in samples containing other viral agents (Williams et al., 1994). When there are outbreaks of the disease, viral detection by real-time PCR is more sensitive in comparison with histology, electron microscopy, isolation in embryonated eggs, and IF. However, because many laboratories do not have the capacity to perform real-time PCR, ILTV diagnosis is routinely made using histopathology, IF, and PCR (Crespo et al., 2007). A new method for detecting ILTV nucleic acid was recently developed: the loop mediated isothermal amplification (LAMP). A comparison of this method with the real-time PCR showed that both are highly specific and sensitive. However, as the LAMP method is faster, less expensive, and does not require a thermocycler compared with real-time PCR, it could be used for routine laboratory diagnosis and real-time PCR can be used for further verification (Ou et al., 2012).

\section{Differential Diagnosis}

Infectious laryngotracheitis need to be differentiated from other respiratory diseases, such as avian pox diphtheria, Newcastle's disease, avian influenza, and those cause by pathogens, including the infectious bronchitis virus, fowl adenovirus, and Aspergillus spp (Garcia et al., 2014).

\section{Prevention}

It is very important to prevent contact between unvaccinated birds with vaccinated birds or with those recovering from an outbreak, which requires good management and biosecurity practices, as well as outbreak control. Biosecurity measures include protocols and procedures to prevent the infection and transmission of birds by humans, insects, wild birds, and other animals (Kingburry et al., 1958; Ou et al., 2012). Recently were used to control of outbreaks geographic information systems that provided information from a region for making plans of biosecurity, quarantine, vaccination and the route where the slaughterhouse of animals and early diagnosis, proper vaccination and cooperation between government and industry are very important for the control of laryngotracheitis (Dufor-Zavala, 2008; Chin et al., 2009).

\section{Treatment}

To date, no drug has shown efficacy in reducing the severity of lesions or relieving symptoms of ILTV. Antibiotics have no effect against the virus, but may control possible secondary bacterial infection (Guy \& Garcia, 2008). However, if ILTV is diagnosed early in an outbreak, unaffected birds may be vaccinated, protecting them before they are exposed to the disease (Garcia et al., 2014).

\section{ILT STATUS IN SOUTH AMERICA}

\section{Brazil}

In Brazil, ILTV was isolated and identified in chickens with respiratory signs, severe hemorrhagic tracheitis, and high mortality in Petrópolis, state of Rio de Janeiro (Hipólito et al., 1974) in 1974, and in 1980 , the virus was again isolated and characterized as a low-pathogenicity virus for broilers (Soares et al., 1980). The first epidemics was reported in 10-monthold laying hens, which presented egg-production drop and mortality in 1981-1982 in the state of Rio de Janeiro (Araujo et al., 1982). In 1995, Vargas (1995) detected antibodies against ILTV in layer farms in the state of Rio Grande do Sul (Vargas, 1995). By the end of 2002, suspected outbreaks of infectious laryngotracheitis were reported in commercial layers in the region of Bastos and Tupã cities in the state of São Paulo (Ito et al., 2003). The virus was isolated in embryonated eggs by Lanagro-SP Laboratory, detected by PCR and molecularly characterized at the University of São Paulo (Chacon et al., 2007; Chacon \& Ferreira, 2008; Chacon \& Ferreira, 2009). At that time, the control measures to prevent the spread of the disease by the farmers, under the coordination of health authorities, were quarantine and also started vaccination with live vaccines CEO and TCO vaccines. The disease had great impact on the region, where more than a million of laying hens died as an outcome of severe injuries in the trachea 
(Chacon \& Ferreira, 2008). The epidemics affected all farms in the region, but at different intensities, possibly due to different levels of biosecurity applied in the poultry farms. Broiler production was the most affected (Chacon et al., 2007; Chacon et al., 2015). The use of PCR-RFLP and analysis of sequences of the ICP4 gene of field isolates of the 2002-2003 clinical outbreak in Bastos showed that the outbreak was caused by a highly virulent non-vaccine strain, which continues circulating in the region of Bastos, despite the vaccination program implemented (Chacon et al., 2010; Parra et al., 2015b). In 2012, a new vaccine vector against infectious laryngotracheitis (FP Vectormune LT), developed by CEVA Animal Health, was presented to the poultry farmers of the region of Bastos (http://www.portalsuinoseaves.com.br/cevalanca-nova-vacina-contra-laringotraqueite-em-aves/). This is a vaccine vector using the pox virus genetically modified to express key protective antigens against the ILT virus. (http://www.ceva.com.br/EspeciesProdutos/Lista-de-Produtos/VECTORMUNE-FP-LT).

Another vaccine available in Brazil is a recombinant vaccine, using as vector HVT (herpesvirus of turkeys) encoding ITLV glycoprotein genes I ( $\mathrm{gl}$ ) and $\mathrm{gD}$ of (Innovax®-ILT; Intervet International BV, Whitehouse Station, NJ, USA) (Couto, 2014).

In the state of Minas Gerais, there was an outbreak in the 2010 in multi-age laying hen farms (Preis et al., 2013), caused by a low-virulence field strain. The Brazilian authorities authorized the use of only vectored vaccines in this region for the prevention of new cases (Couto et al., 2014). Recent studies show that both the CEO and the TCO vaccine viruses are still circulating in commercial layer flocks in different regions of Brazil (Chacon et al., 2015; Parra et al., 2015b).

\section{Argentina}

In Argentina, there are periodic ILT outbreaks, especially in areas with high density of industrial poultry farms with poor management and biosecurity measures, in farms that rear both broilers and layers, and, in some cases, also backyard birds. These outbreaks are usually caused by the transmission of the virus from infected birds exposed to field virus or from birds vaccinated with CEO vaccines. The use and marketing of such vaccines have currently been suspended in Argentina by a provision of the Directorate of Agricultural Chemicals, Pharmaceuticals and Veterinary SENASA No. 1559/2007 http://www. senasa.gov.ar/Archivos/File/File2821-laringotraqueitisinfecciosa.pdf) (Back \& Leão, 2003).

\section{Peru}

Infectious laryngotracheitis was reported for the first time in Peru in August 2008 (Leisequia, 2013), and caused high morbidity and mortality. The affected poultry farms were in the Department of Lima, and ILT was later reported in the departments of Arequipa, Ancash, Ica, La Libertad, and Tacna (OIE Wahid Interface, 2010). The main lesions described in laying hens and fighting roasters were inflammation of the nasal and paranasal sinuses, serum hemorrhagic or hemorrhagic discharge, inflammation of the eyelids and conjunctivitis, presence of caseous material in the palate, diphtheritic plaques on the esophagus and larynx, hemorrhagic clots in the trachea. In broilers, inflammation of the eyelids and conjunctivitis and bleeding in the trachea were the most common findings. Different vaccination programs with a vaccine vector were used on different farms and had a clear positive impact and benefit on the control of the disease (http://amevea-ecuador.org/datos/ LARINGOTRAQUEITIS \% 20INFECCIOSA \% 20LA \% 20 EXPERIENCIA\%20PERUANA.pdf).

\section{Ecuador}

In the first half of 2012, infectious laryngotracheitis was reported by the first time in Ecuador. The virus was detected by PCR in the cities of La Concordia, Pillaro, and Salcedo, but the source of infection was unknown (unpublished data). The University San Francisco de Quito carried out a detailed investigation between March 2011 and March 2012. Samples were collected in the provinces of Pichincha, La Concordia, Tungurahua, Cotopaxi, Manabí, Guayas, and Chimborazo, and PCR-positive results were obtained in samples from the provinces of Cotopaxi, Tungurahua, and La Concordia. The results were delivered to the governmental agency AGROCALIDAD (Agencia Aseguradora de la Calidad del Agro) in May 2012. This agency collected its own samples and confirmed the results. AGROCALIDAD also evaluated population density, history of respiratory symptoms compatible with the disease, bird age and type of production (http://www.veterinaria.org/ revistas/vetenfinf/nfondevila/liecuador2012.htm).

\section{Bolivia}

The most common poultry diseases in the valleys of Cochabamba are mycoplasmosis, salmonellosis, with a minor incidence of bronchitis. In the first half of 2005, four cases of laryngotracheitis were recorded (http://www.midiatecavipec.com/avicultura/ avicultura020908.htm). ILTV was also reported in 
Uruguay, Colombia and Chile (Hidalgo, 2003; Back \& Leão, 2003).

\section{Colombia}

ILT was confirmed for the first time in the Department of Valle del Cauca in 1971 in chickens with respiratory distress, coughing, conjunctivitis, and lacrimation. The chickens were necropsied at the Diagnostic Center ICA in Cali and presented the following lesion: beak with bloody and mucoid exudate, different degrees of laryngitis and tracheitis, bloody serous exudate in the trachea of some birds and others with cheesy yellowish exudate, tracheal mucosa covered with a pseudomembrane composed of fibrin and necrotic tissue partially or completely occluding the tracheal lumen. The disease was confirmed by medical history, macroscopic and microscopic (histopathology) lesions, and viral isolation (Morales, 1971) in chicken embryonated eggs with 10- to 12-day-old via MCA. The virus identification was confirmed by serum neutralization tests (Villate, 1971). In 1978, the Animal Health services of Colombia, which are in charge of the Colombian Agricultural Institute, ICA, under the Ministry of Agriculture, prepared a document containing general country information (location, size, climate, land use) farm; animal health status in Colombia; the organization of the Animal Health Division of (services: diagnosis, inspection of refrigerators, quarantine, health campaigns, FMD control, brucellosis), animal species, and main diseases, which included the laryngotracheitis; and animal health legislation (Estupiñan, 1978). In documents of OIE 2015, ILT was not reported in that year (http:// www.cabi.org/isc/datasheet/79280).

\section{Venezuela}

In 1963, ILT was mentioned in a Poultry Conference in Maracay (Ayala Lopez, 1963) and in 1982, the use of vaccines against laringotraqueitis was mentioned (Quiroz et al., 1982). According to the OIE, the disease was not reported in 2015 (http://www.cabi.org/isc/ datasheet/79280).

\section{Paraguay}

The resolution 2400 issued in 2015 by the Paraguayan Animal Health and Quality Service (SENACSA, Servicio Nacional de Calidad y Salud Animal), belonging to the Ministry of Agriculturw of Paraguay updated the list of notifiable diseases and included infectious laryngotracheitis. That resolution provides that the notification of suspected of confirmed diseases in the list is mandatory by all farmers and veterinarians who work in the area of animal health or diagnosis (http://www.senacsa. gov.py/application/files/7714/4582/8020/SENACSARES-2400-2015.pdf).

\section{Uruguay}

A study between 2008 and 2009 on farms located in the areas of Montevideo, Canelones, and Lavalleja showed an ILT seroprevalence of $31.5 \%$ in unvaccinated broiler using a software, which applied applying Bayesian inference methodology Monte Carlo based on Markov Chains (MCMC). The study concluded that the results may be attributed to natural exposure to field virus and/or vaccine virus of birds in neighboring farms (Trenchi, et al., 2012).

\section{FINAL REMARKS}

The presence of the ILT in South America is evidenced by the reported outbreaks and the economic losses caused in poultry production, confirming that infectious laryngotracheitis has worldwide distribution. For this reason, it is important that good management and biosecurity practices are developed, improved, and implemented for its prevention and control. Management practices, new vaccines (recombinants), and a strict biosecurity measures can prevent economic losses and may also reverse the latency of the virus in all South American countries. It is important also to be updated of new information on specific clinical signs, epidemiology of disease, and associated diseases, especially immunosuppressive diseases, as well as on the immune status of flocks to prevent new outbreaks.

\section{ACKNOWLEDGMENT}

This work was supported by grants from Conselho Nacional de Desenvolvimento Cientifico e Tecnológico (CNPq Grants no. 453920/2014-4 and 306380/20145), and Fundação de Amparo à Pesquisa do Estado de São Paulo (FAPESP Grant no. 2013/08560-5). Antonio J. Piantino Ferreira was granted a CNPq fellowship.

\section{REFERENCES}

Andreasen JR, Glisson JR, Gooddwin MA, Resurreccion RS, Villegas P, Brown J. Studies of infectious laryngotracheitis vaccines:Immunity in layers. Avian Diseases 1989;33:524-530.

Araújo LMG, Silva RCF, Santos JA, Bonaccorsi RA, Bittencourt NRA, Gomes TA. Estudo sobre um foco de Laringotraqueíte infecciosa das galinhas no município de Petropólis/RJ;características fundamentais da doença e do vírus. PESAGRO-RIO 1982;10:1-4. 
Ayala Lopez, R. Diftero Viruela y Laringotraqueitis infecciosa de las aves. Anais do Seminario sobre Avicultura; 1963; Maracay, Aragua. Venezuela; 1963. p. 7793

Back A, Leão JA. Laringotraqueíte. Anais do $4^{\circ}$ Simpósio Brasil Sul de Avicultura; 2003; Chapecó, Santa Catarina. Brasil; 2003. p. 50-56.

Bagust TJ, Calnek BW, Fahey KJ. Gallid-1 herpesvirus infection in the chicken. 3. Reinvestigation of the pathogenesis of infectious laryngotracheitis in acute and early post-acute respiratory disease. Avian Diseases 1986;30:179-190.

Bagust TJ, Johnson MA. Avian infectious laryngotracheitis: virus-host interactions in relation to prospects for eradication. Avian Pathology 1995;24:373-391.

Bagust TJ, Jones RC, Guy JS. Avian infectious laryngotracheitis. Revue Scientifique et Tecnique-Office International des Epizooties 2000;19:483-492.

Bagust TJ. Laryngotracheitis (Gallid-1) herpesvirus infection in the chicken. 4. Latency establishment by wild and vaccine strains of ILT virus. Avian Pathology 1986;15:581-595.

Bautista D. Isolation of infectious laryngotracheitis vírus (ILTV) from peafowls and chickens with a history of respiratory diseases. Proceeding of the 140th AVMA Annual Convention; 2003; Colorado Springs, Colorado. USA; 2003. p. 24.

Benton WJ, Cover MS, Krauss WC. Studies on parental immunity to Infectious Laryngotracheitis of Chickens. Avian Diseases 1960;4:491499.

Chacón JL, Brandao PEB, Villareal LYB, Gama NM, Ferreira AJP. Survey of infectious laryngotracheitis outbreak in layer hens and differential diagnosis with other respiratory pathogens. Brazilian Journal of Poultry Science 2007;9:61-67.

Chacón JL, Ferreira AJP. Development and validation of nested-PCR for the diagnosis of clinical and subclinical infectious laryngotracheitis. Journal of Virological Methods 2008;151:188-193.

Chacón JL, Ferreira AJP. Differentiation of field isolates and vaccine strains of infectious laryngotracheitis virus by DNA sequencing. Vaccine 2009;27:6731-6738

Chacón JL, Mizuma MY, Piantino Ferreira AJ. Characterization by restriction fragment length polymorphism and sequence analysis of field and vaccine strains of infectious laryngotracheitis virus involved in severe outbreaks. Avian Pathology 2010;39:425-433.

Chacón JL, Núñez LFN, Vejarano MP, Parra SHS, Astolfi-Ferreira CS, Ferreira AJP. Persistence and spreading of field and vaccine strains of infectious laryngotracheitis virus (ILTV) in vaccinated and unvaccinated geographic regions, in Brazil. Tropical Animal Health and Production 2015;47:1101-1108

Chacon JL. Vírus da laringotraqueíte infecciosa: detecção e caracterização molecular, isolamento, diagnóstico diferencial e epidemiologia de um surto em granjas de poedeiras comerciais na região de Bastos, Estado de São Paulo [dissertation]. São Paulo (SP): Universidade de São Paulo; 2008.

Chang $P C$, Lee $Y L$, Shien $J H$, Shieh HK. Rapid differentiation of vaccine strains and field isolates of infectious laryngotracheitis virus by restriction fragment length polymorphism of PCR products. Journal of Virology Methods 1997;66:179-186.

Chen HY, Zhao L, Wei ZY, Cui BA, Wang ZY, Li XS, et al. Enhancement of the immunogenicity of an infectious laryngotracheitis virus DNA vaccine by a bicistronic plasmid encoding glycoprotein B and interleukin-18. Antiviral Research 2010;87:235-241.
Chin RP, García M, Corsiglia C, Riblet S, Crespo R, Shivaprasad HL, et al. Intervention strategies for laryngotracheitis: impact of extended downtime and enhanced biosecurity auditing. Avian Diseases 2009;53:574-577.

Clarke JK, Robertson GM, Purcell DA. Spray vaccination of chicken using infectious laryngotracheitis virus. Australian Veterinary Journal 1980;56:424-428.

Coppo MJC, Hartley CA, Devlin JM. Immune responses to infectious laryngotracheitis virus. Developmental and Comparative Immunology 2013b;41:454-462.

Coppo MJC, Noormohammadi AH, Browning GF, Devlin JM. Challenges and recent advancements in infectious laryngotracheitis virus vaccines. Avian Pathology 2013a;42:195-205.

Couto RM, Preis IS, Braga JFV, Brasil BSAF, Drummond MG, Martins NRS, et al. Molecular characterization of infectious laryngotracheitis virus in naturally infected egg layer chickens in a multi-age flock in Brazil. Archives of Virology 2014;160:241-252.

Couto RM. Caracterização patológica e molecular do vírus da laringotraqueíte infecciosa e diagnóstico diferencial em aves comerciais no estado de Minas Gerais [dissertation]. Belo Horizonte (MG): UFMGEscola de Veterinária; 2014.

Crawshaw GJ, Boycott BR. Infectious Laryngotracheitis in peafowl and pheasants. Avian Diseases 1982;26:397-401.

Crespo R, Woolcock PR, Chin RP, Shivaprasad HL, Garcia M. Comparison of Diagnostics Techniques in an Outbreak of Infectious Laryngotracheitis from Meat Chickens. Avian Diseases 2007;51:858-862.

Davison S, Gingerich EN, Casavant S, Eckroade RJ. Evaluation of the Efficacy of a Live Fowlpox-Vectored Infectious Laryngotracheitis/Avian Encephalomyelitis Vaccine Against ILT Viral Challenge. Avian Diseases 2006;50:50-54

Devlin JM, Browning GF, Gilkerson JR, Fenton SP, Hartley CA. Comparison of the safety and protective efficacy of vaccination with glycoproteinG-deficient infectious laryngotracheitis virus delivered via eye-drop, drinking water or aerosol. Avian Pathology 2008;37:83-88.

Devlin JM, Browning GF, Hartley CA, Kirkpatrick NC, Mahmoudian A, Noormohammadi $A H$, et al. Glycoprotein $G$ is a virulence factor in infectious laryngotracheitis virus. Journal of General Virology 2006;87:2839-2847.

Dufor-Zavala L. Epizootiology of infectious laryngotracheitis and presentation of a industry control program. Avian Diseases 2008;52:17.

Estupiñan Arias, J. Colombia: sanidad animal. Ica: Instituto Colombiano Agropecuario 1978:90

Fahey KJ, Bagust TJ, York JJ. Laringotracheitis herpesvirus infection in the chicken:The role of humoral antibody in immunity to a graded challenge infection. Avian Pathology 1983;12:505-514.

Fahey KJ, York JJ. The role of mucosal antibody in immunity to infectious laryngotracheitis virus in chickens. Journal of General Virology 1990;71:2401-2405

Fuchs W, Wiesner D, Veits J, Teifke JP, Mettenleiter TC. In Vitro and in Vivo Relevance of Infectious Laryngotracheitis Virus gJ Proteins That Are Expressed from Spliced and Nonspliced mRNAs. Journal of Virology 2005;79:705-716.

Garcia M, Spatz S, Guy JS. Infectious Laringotracheitis. In: Saif YM, Glisson JR, Fadly AM, Mcdougald LR, Nolan LK, Swayne DE, editors. Diseases of poultry. Ames: lowa State Press; 2014. p. 161-79. 
Gharaibeh S, Mahmoud K, Al-Natour M. Field evaluation of maternal antibody transfer to a group of pathogens in meat-type chickens. Poultry Science 2008;87:1550-1555.

Guy JS, Barnes HJ, Smith L. Increased virulence of modified-live infectious laryngotracheitis vaccine virus following bird-to-bird passage. Avian Diseases 1991;35:348-355.

Guy JS, Barnes HJ, Smith LG. Rapid diagnosis of infectious laryngotracheitis using a monoclonal antibody based immunoperoxidase procedure. Avian Pathology 1992;21:77-86.

Guy JS, Garcia M. Laryngotraqueitis. In: Saif YM, Glisson JR, Fadly AM, Mcdougald LR, Nolan LK, Swayne DE, editors. Diseases of poultry. Ames: lowa State Press; 2008. p. 137-152.

Han MG, Kweon, CH, Mo IP, Kim SJ. Pathogenicity and vaccine efficacy of a thymidine kinase gene deleted infectious laryngotracheitis virus expressing the green fluorescent protein gene. Archives of Virology 2002;147:1017-1031.

Helferich D, Veits J, Mettenleiter TC, Fuchs W. The UL47 gene of avian infectious laryngotracheitis virus is not essential for in vitro replication but is relevant for virulence in chickens. Journal of General Virology 2007;88:719-731.

Hidalgo H. Infectious Laryngotracheitis: a review. Brazilian Journal of Poultry Science 2003;5:157-168.

Hipólito O, Soares LA, Pereira OAC, Pinto AA, Bottino JA. Isolamento e identificação do vírus da laringotraqueíte infecciosa das galinhas no Brasil. Anais do $5^{\circ}$ Congresso Brasileiro de Microbiologia; 1974; Rio de Janeiro, Rio de Janeiro. Brasil. p. 16.

Hitchner SB and White PG. A comparison of embryo and bird infectivity using five strains of laryngotracheitis virus. Poultry Science 1958;37:648-690.

Hughes CS, Gaskell RM, Jones RC, Bradbury JM, Jordan FT. Effects of certain stress factors on the re-excretion of infectious laryngotracheitis virus from latently infected carrier birds. Reserch in Veterinary Science $1989 ; 46: 274-276$

Hughes CS, Jones RC. Comparison of cultural methods for primary isolation of infectious laryngotracheitis virus from field material. Avian Pathology 1988; 17:295-303.

Hughes CS, Williams RA, Gaskell RM, Jordan FTW, Bradbury JM, Bennett $M$, et al. Latency and reactivation of infectious laryngotracheitis vaccine virus. Archives of Virology 1991;121:213-18.

Ito NMK, Gama NMSQ, Miyaji Cl, Okabayashi S, Lima EM, Babadopulos P. Diagnóstico da laringotraqueíte infecciosa das galinhas. Brazilian Journal of Poultry Science 2003; Suplemento 5:118.

Johnson MA, Prideaux CT, Kongsuwan K, Sheppard M, Fahey KJ. Gallid herpesvirus 1 (infectious laryngotracheitis virus):Cloning and physical maps of the SA-2 strain. Archives of Virology 1991;119:181-198.

Johnson MA, Tyack SG. Molecular evolution of infectious laryngotracheitis virus (ILTV; gallid herpesvirus 1):an ancient example of the Alphaherpesviridae? Veterinary Microbiology 1995;46:221-231.

Johnson YJ, Gedamu N, Colby MM, Myint MS, Steele SE, Salem M, et al. Wind-borne transmission of infectious laryngotracheitis between commercial poultry operations. International Journal of Poultry Science 2005;4:263-267.

Jordan FTW, Chubb RC. The agar gel diffusion technique in the diagnosis of infectious layngotracheitis (ILT) and its diferentiation from fowl pox. Reserch in Veterinary Science 1962;3:245-255.

Jordan FTW. A review of the literature on the infectious laryngotracheitis (ILT). Avian Diseases 1966;10:1-26.
Jordan FTW. Immunity to infectious laryngotracheitis. In: Ross ME, Payne LN, Freeman BM. editors. Avian immunology. Edinburg: British Poultry Science; 1981. p. 245-254.

Keam L, York JJ, Sheppard M, Fahey KJ. Detection of infectious laryngotracheitis virus in chickens using a non-radioactive DNA probe. Avian Diseases 1991;35:257-262.

Key DW, Gough BC, Derbyshire JB, Nagy E. Development and Evaluation of a Non-isotopically Labeled DNA Probe for the Diagnosis of Infectious Laryngotracheitis. Avian Diseases 1994;38:467-474

King AMQ, Adams MJ, Carstens EB, Lefkowitz EJ. Ninth Report of the International Committee on Taxonomy of Viruses. San Diego: Elsevier Academic Press; 2012; p. 1344.

Kingsbury FW, Jungherr EL. Indirect transmission of infectious laryngotracheitis in chickens. Avian Diseases 1958;2:54-63.

Kirkpatrick NC, Mahmoudian A, O'Rourke D, Noormohammadi AH. Differentiation of infectious laryngotracheitis virus isolates by restriction fragment length polymorphic analysis of polymerase chain reaction products amplified from multiple genes. Avian Diseases 2006:50:28_ 34.

Kotiw M, Wilks CR, May JT. The effect of serial in vivo passage on the expression of virulence and DNA stability of an infectious laryngotracheitis virus strain of low virulence. Veterinary Microbiology 1995;45:71-80

Leisequia LML. Impacto Económico de Laringotraqueitis infecciosa aviar en una granja de pollos de carne del departamento de Lima [dissertation]. Lima (PE): Universidad Nacional Mayor de San Marcos; 2013.

May HG, Tittsler RP. Tracheolaryngotracheitis in poultry. Journal of American Veterinarian Medical Association 1925;67:229-231.

Menendez KR, García M, Spatz S, Tablante NL. Molecular epidemiology of infectious laryngotracheitis:a review. Avian Pathology 2014;43:108117.

Morales, GGA. Laringotraqueitis infecciosa aviar en Colombia:características y diagnóstico histopatológico. Revista ICA (Colombia) 1971;6:181-189.

Nagy E. Detection of infectious laryngotracheitis virus infected cells with cloned DNA probes. Canadian Journal of Veterinary Research $1992 ; 56: 34-40$

Neighbour NK, Newberry LA, Bayyari GR, Skeeles JK, Beasley JN, McNew RW. The effect of microaerosolized hydrogen peroxide on bacterial and viral poultry pathogens. Poultry Science 1994;73:1511-1516.

Nielsen OL, Handberg KJ, Jorgensen PH. In situ hybridization for the detection of infectious laryngotracheitis virus in section of trachea from experimentally infected chickens. Acta Veterinaria Scandinava 1998;39:415-421.

Oldoni I, Rodríguez-Avila A, Riblet SM, Zavala G, García M. Pathogenicity and growth characteristics of selected infectious laryngotracheitis virus strains from the United States. Avian Pathology 2009;38:47-53.

Ou SC, Giambrone JJ, Macklin KS. Comparison of a TaqMan real-time polymerase chain reaction assay with a loop-mediated isothermal amplification assay for detection of Gallid herpesvirus 1. Journal of Veterinary Diagnostic Investigation 2012;24:138-141.

Ou SC, Giambrone JJ, Macklin KS. Detection of infectious laryngotracheitis virus from darkling beetles and their immature stage (lesser mealworms) by quantitative polymerase chain reaction and virus isolation. Journal Applied Poultry Research 2012a;21:33-38

Ou SC, Giambrone JJ, Macklin KS. Infectious laryngotracheitis vaccine virus detection in water lines and effectiveness of sanitizers for inactivating the virus. Journal of Applied Poultry Research 2011;20:223-230. 
Ou SC, Giambrone JJ. Infectious laryngotracheitis virus in chickens. World Journal of Virology 2012b;1:142-149.

Parra SH, Nuñez LF, Astolfi-Ferreira CS, Ferreira JP. Persistance of the tissue culture origin vaccine for infectious laryngotracheitis virus in commercial chicken flocks in Brazil. Poultry Science 2015b;94:2608-2615.

Parra SHS, Nuñez LFN, Astolfi-Ferreira CS, Ferreira AJP. Ocurrence of Infectious Laryngotracheitis Virus (ILTV) in 2009-2013 in the State of São Paulo - Brazil. Brazilian Journal of Poultry Science 2015a;17:117120.

Pavlova SP, Veits J, Blohm U, Maresch C, Mettenleiter TC, Fuchs W. In vitro and in vivo characterization of glycoprotein C-deleted infectious laryngotracheitis virus. Journal of General Virology 2010;91:847-857.

Pavlova SP, Veits J, Keil GM, Mettenleiter TC, Fuchs W. Protection of chickens against $\mathrm{H} 5 \mathrm{~N} 1$ highly pathogenic avian influenza virus infection by live vaccination with infectious laryngotracheitis virus recombinants expressing $\mathrm{H} 5$ hemagglutinin and $\mathrm{N} 1$ neuraminidase. Vaccine 2009;27:773-785.

Pirozok RP, Helmbolt CF, Jungherr EL. A rapid histological technique for the diagnosis of infectious avian laryngotracheitis. Journal of American Veterinarian Medical Association 1957;130:406-407.

Portz C, Beltrao N, Furian TQ, Júnior AB, Macagnan M, Griebeler J, et al. Natural infection of turkeys by infectious laryngotracheitis virus. Veterinary Microbiology 2008;131:57-64.

Preis IS, Braga JFV, Couto RM, Brasil BSAF, Martins NRS, Ecco R. Outbreak of infectious laryngotracheitis in large multi-age egg layer chicken flocks in Minas Gerais, Brasil. Pesquisa Veterinária Brasileira 2013;33:591-596.

Quiroz C, Noguera C, Infante D, Leon A. Tipos de vacunas contra enfermedades de las aves que se usan en Venezuela. Fonaip Divulga (Venezuela) 1982;1:2529.

Raggi LG, Brownell JR, Stewart GF. Effect of infectious laryngotracheitis on egg production and quality. Poultry Science 1961;40:134-140.

Robertson GM, Egerton JR. Replication of infectious laryngotracheitis vírus in chickens following vaccination. Australian Veterinary Journal 1981;57:119-123.

Rodríguez-Avila A, Oldoni I, Riblet S, García M. Replication and Transmission of Live Attenuated Infectious Laryngotracheitis Virus (ILTV) Vaccines. Avian Diseases 2007;51:905-911.

Schnitzlein WM, Radzevicius J, Tripathy DN. Propagation of Infectious Laryngotracheitis Virus in an Avian Liver Cell Line. Avian Diseases 1994;38:211-217.

Sellers HS, García M, Glisson JR, Brown TP, Jean S, Guy JS. Mild Infectious Laryngotracheitis in Broilers in the Southeast. Avian Diseases 2004:48:430-436.

Sevoian M. A quick method for the diagnosis of avian pox and infectious laryngotracheitis. Avian Diseases 1960;4:474-77.

Soares LA, Pereira OAC, Hipólito O. Characterization of the first strain of infectious laryngotracheitis virus (ILTV) in Brazil chicken. Revue of Microbiology 1980;11:104-109.
Tong GZ, Zhang SJ, Meng SS, Wang L, Qui HJ, Wang YF, et al. Protection of chickens from infectious laryngotracheitis with a recombinant fowlpox virus expressing glycoprotein B of infectious laryngotracheitis virus. Avian Pathology 2001;30:143-148.

Trenchi G, Suzuki K, Corva SG, Rodríguez G, Trenchi H, Petruccelli M Stochastic estimation for seroprevalence of infectious laryngotracheitis virus in broilers in Uruguay. Analecta Veterinaria 2012;32:57-60.

Vagnozzi A, Zavala G, Riblet SM, Mundt A, García M. Protection induced by comercially available live-attenuated and recombinant viral vector vaccines against infectious laryngotracheitis virus in broiler chickens. Avian Pathology 2012;41:21-31.

Vargas RES. Laringotraqueíte infecciosa das aves: estudo epidemiológico em plantéis avícolas no Estado do Rio Grande do Sul [dissertation]. Porto Alegre (RS): Universidade Federal de Rio Grande do Sul; 1995.

Veits J, Luschow D, Kindermann K, Werner O, Teifke JP, Mettenleiter TC, et al. Deletion of the non-essential ULO gene of infectious laryngotracheitis (ILT) virus leads to attenuation in chickens, and ULO mutants expressing influenza virus haemagglutinin (H7) protect against ILT and fowl plague. Journal of General Virology 2003;84:3343-3352.

Villate Granados, JE. Laringotraqueitis infecciosa aviar en Colombia: diagnóstico histopatológico, aislamiento del virus y reproducción experimental. Anais do $8^{\circ}$ Congreso Nacional y Medicina Veterinaria y Zootecnia; Nov 1971; Cúcuta. Colômbia; 1971. p. 4243.

Wang LG, Ma J, Xue CY, Wang W, Guo C, Chen F, et al. Dynamic distribution and tissue tropism of infectious laryngotracheitis virus in experimentally infected chickens. Archives of Virology 2013;158:659-666.

Wilks CR, Kogan VG. An immunofluorescence diagnostic test for avian infectious laryngotracheitis. Australian Veterinary Journal 1979:55:385-388.

Williams RA, Bennett M, Bradbury JM, Gaskell RM, Jones RC, Jordan FTW. Demonstration of sites of latency of infectious laryngotracheitis virus using the polymerase chain reaction. Journal of General Virology $1992 ; 73: 2415-2420$

Williams RA, Savage CE, Jones RC. A comparison of direct electron microscopy, virus isolation and a DNA amplification method for the detection of avian infectious laryngotracheitis virus in field material. Avian Pathology 1994;23:709-720.

Yamada S, Matsuo K, Fukuda T, Uchinuno Y. Susceptibility of ducks to the virus of infectious laryngotracheitis. Avian Diseases 1980;24:930-938.

York JJ, Fahey KJ. Humoral and cell-mediated immune responses to the glycoproteins of infectious laryngotracheitis herpesvirus. Archives of Virology 1990;115:289-297.

York JJ, Young JG, Fahey KJ. The appearance of viral antigen and antibody in the trachea of naive and vaccinated chickens infected with infectious laryngotracheitis virus. Avian Pathology 1989;18:643-658.

Zhao Y, Kong C, Cui X, Cui H, Shi X, Zhang X, et al. Detection of infectious laryngotracheitis virus by real-time PCR in naturally and experimentally infected chickens. PloS ONE 2013;8:1-10. 
